DRAGANA PETROVIĆ, Ph.D. ${ }^{1}$

(Corresponding author)

E-mail: dragana.petrovic@sf.bg.ac.rs

IVAN IVANOVIĆ, Ph.D. ${ }^{1}$

E-mail: i.ivanovic@sf.bg.ac.rs

VLADIMIR ĐORIĆ, Ph.D. ${ }^{1}$

E-mail: v.djoric@sf.bg.ac.rs

JADRANKA JOVIĆ, Ph.D. ${ }^{1}$

E-mail: j.jovic@sf.bg.ac.rs

${ }^{1}$ University of Belgrade

Faculty of Transport and Traffic Engineering

Vojvode Stepe 305, 11000 Belgrade, Serbia
Traffic Planning

Review

Submitted: 29 Jan. 2020

Accepted: 11 May 2020

\title{
IMPACT OF WEATHER CONDITIONS ON TRAVEL DEMAND - THE MOST COMMON RESEARCH METHODS AND APPLIED MODELS
}

\begin{abstract}
This paper presents an overview of the applied research methodologies and developed travel demand models that take weather impact into account. The paper deals with trip generation and modal split as elements of travel demand that best describe changes in the travel behaviour in different weather conditions. The authors herein emphasize the importance of research in local conditions in all climate zones, especially in areas where climate and modal split characteristics are different from those in common research areas. This review is designed as a brief guide on how the impact of weather can be explored in order to encourage conducting research even in the countries where there is no systematic traffic and travel data collection. The stated adaptation technique followed by the panel household travel surveys may be particularly appropriate for those countries. It is concluded that small budgets should not be considered an obstacle, because it is possible to draw reliable conclusions based even on small samples. Moreover, modern research methods enable a cheaper survey process together with the possibility of obtaining higher quality of results. The increasing popularity of research in this field should contribute to the creation of more resilient transport systems all over the world. A special contribution of this paper is the review of research studies carried out in central, western and southern Europe and not mentioned in any review paper before.
\end{abstract}

\section{KEY WORDS}

weather impact; travel behaviour; trip generation; modal split;

\section{INTRODUCTION}

The transport system is becoming unreliable in adverse weather conditions, particularly in densely populated areas. It is general opinion [1-5] that impacts of climate change and weather conditions on the transport system have not received the necessary attention. Traffic data are collected mainly in good weather conditions during the spring and autumn. Most models used in transportation planning and traffic management do not include parameters that indicate the weather impact, so they are customized for ideal weather conditions $[5,6]$. For a long period of time the weather conditions have been generally left out of travel demand studies, or simplified $[2,3,7]$.

Nowadays, in most research papers, the impact of weather on the transport system is analysed through its effect upon traffic infrastructure, driver behaviour, and traffic safety. Common weather condition components including rain, snow, and ice could have apparent negative impacts on the transport system like changing the travel demand, reducing capacity, compromising safety conditions, travel mobility, and reliability [8]. In addition to having an impact on the transport system, technical and operational characteristics, adverse weather surely affects the individuals' decisions and consequently, the travel demand. It is known that transport systems operating close to full capacity react highly non-linearly to changes in travel demand, especially to additional travel demand [9]. Adverse 
weather might lead to delay, trip postponement, or modal shift, which may further contribute to congestion, especially during peak hours. Recent studies have demonstrated a sizeable impact of weather, primarily on trip generation, choice of destination, and modal split [1] and suggested that weather conditions should be included in traffic demand models $[2,9]$. The majority of research papers analyse the weather impact on non-motorized transport due to its greatest exposure to weather conditions.

Therefore, studies about weather impact on travel demand, trip generation and modal split have been most frequently conducted in cities with significant share of non-motorized trips. The fact is that significant changes, especially in the modal split, can be expected under adverse weather influence in these cities. For example, according to Guitink et al. 1994 [10] forty to sixty percent of all trips are made by walking and cycling in medium-sized cities in Germany and the Netherlands and nowadays medium-sized cities in these countries have a non-motorized share of about $20 \%$ to $60 \%$. It is interesting that non-motorized travel are mostly walking trips in Germany and bicycle trips in the Netherlands. There are almost 600 cities/city-regions in Europe which are considered as medium-sized, with a population between 100,000 and 500,000 inhabitants [11]. Exploring the impact of weather conditions on travel demand can be of particular importance in all cities with these characteristics. In Germany, even in major cities, non-motorized movements are widely represented with a greater share of pedestrian movements compared to cycling [12] which can be seen in detail at the European Platform on Mobility Management [13]. Some studies [14-18] show that adverse weather has the strongest effect on bicycle trips. However, this effect certainly depends on cultural differences of the residents. In the Netherlands, a significant share of bicycles in the modal split during windy, rainy, and cold days [19] results from a long tradition of bicycle use.

Climatic and weather conditions vary significantly across the world and consequently, weather conditions are expected to have different impacts on travel demand in different climate zones. When estimating transport demand over a longer period of time and under expected climate change, a specific methodology must be applied [20]. The results of weather impact on travel demand acquired on one territory cannot be applied to another $[6,21]$ due to different weather conditions, cultural and socio-economic characteristics of the residents. Böcker et al. [22] point out the geographical context, transport and land use, climate conditions, cultures, habits, and adaptations as the main reasons for differences in the effects of weather on mobility in different countries. Additionally, the perception of service quality, especially in the public transport, exerts a great influence on the travel mode choice [23], and the fact is that the individuals in different areas perceive the quality of the transport system differently. Weather conditions and their effects on traffic demand might also differ very strongly within the same country, regionally and seasonally [6]. Research in the local conditions is very important, as the only method of reliable identification and modelling the weather impact on the travel demand.

There are two perspectives in this literature review. The first comprises the applied research methodologies and the second comprises the developed trip generation and modal split models, analysed weather condition components and the main findings in terms of applied modelling procedures. An overview of the research papers analysing and modelling the impact of weather on trip generation and modal split is presented in the next sections. This review includes papers investigating impacts of weather conditions on all transport modes. There are many papers that investigate the impact of weather conditions on only one mode or on only non-motorized transport modes, but these papers are not the subject of this review. The review shows an increase in the number of research papers dealing with weather impact on the travel demand in the last decade, including three review studies published by authors Koetse and Rietveld [3], Böcker et al. [1] and Liu et al. [24].

The authors of this paper believe that the review of relevant papers given herein will indicate the best examples that may serve as a starting point for such research in the countries where it has not been conducted yet. The most common methodologies used in investigating the weather impact on trip generation and modal split are presented in the first part of this paper. After that, weather variables and applied procedures for modelling trip generation and modal split in different weather conditions are shown. Research studies about the impact of weather conditions upon travel demand conducted in the Central, Western and Southern Europe are singled out and described in the last section, since most of them had 
not been cited or reviewed until now. This is followed by the conclusions and recommendations for further research.

\section{MOST COMMONLY USED RESEARCH METHODOLOGIES}

In most research studies, data on travel demand in different weather conditions were collected by the revealed preferences method, based on household travel survey. The household travel survey is the most common method used in transportation planning for collecting travel demand data [25, 26]. The essence of this technique is to record real changes in travel behaviour. Its main limitation is the inability to test alternatives that are not yet present in the transport system [27, 28].

In addition to the revealed preference method, the stated preference method and the stated adaptation are also used. There are two types of stated preference techniques: the first, where the respondents state their preferences through the measuring scale levels, and the second, where the respondents select one of the offered scenarios or attribute combinations [29]. The stated preference technique enables identification of the user choice for a large number of attribute values. Its main limitation is that the respondents do not necessarily behave as they state in the survey and there is always a possibility of inconsistency between the survey results and the reality. Some studies, however, do not show any statistically significant difference between the user statements and their actual behaviour $[25,26]$.

The stated adaptation technique is very similar and it has been increasingly used. It is based on the statements regarding behaviour changes $[28,30]$. The stated preferences technique implies that the respondents present an answer with their preferences regarding the offered scenarios, while in the stated adaptation technique the respondents present an answer whether and how their behaviour would change in the offered scenarios [31], in this case in different weather conditions. The stated adaptation technique provides a clearer insight into individual attitudes and behaviour when facing hypothetical situations, especially concerning traffic conditions $[30,32]$.

The revealed preference method is used in case of comprehensive and long-term household travel surveys. In other cases, the stated preferences and the stated adaptation are completely valid methods of data collection. Continuous household travel surveys are common for the countries and cities with greater awareness of the importance of these surveys and available funding. The travel surveys carried out once every five or ten years, or even less frequently, are common for the developing countries, where sufficient funds are not available. Table 1 shows the research methods and sample sizes in relevant studies, emphasizing the sample size variation.

Table 1 - Applied research methodology and sample size in relevant studies

\begin{tabular}{|c|c|}
\hline Research method & $\begin{array}{c}\text { Sample size } \\
\text { (number of respondents) }\end{array}$ \\
\hline \multicolumn{2}{|c|}{ Revealed preferences } \\
\hline Aaheim and Hauge [7] & 16,383 \\
\hline Anta et al. [36] & 99 \\
\hline Böcker et al. [33] & 945 \\
\hline Böcker et al. [22] & 14,935 \\
\hline Clifton et al. [2] & 2,950 \\
\hline Creemers et al. [37] & 18,102 \\
\hline Liu et al. [18] & 181,814 \\
\hline Liu et al. [38] & 13,579 \\
\hline Liu et al. [39] & 24,987 \\
\hline Petrović 2017 [34] & 392 \\
\hline Rudloff et al. [9] & 193 \\
\hline Sabir [19], Sabir et al. [40] & $1,035,378$ \\
\hline Sabir et al. [41] & 530,000 \\
\hline $\begin{array}{l}\text { Saneinejad et al. [42], } \\
\text { Saneinejad [43] }\end{array}$ & 43.557 \\
\hline Termida et al. [35] & 67 \\
\hline $\mathrm{Vu}$ and Nguyen [44] & 400 \\
\hline \multicolumn{2}{|c|}{ Stated preferences } \\
\hline Anta et al. [36] & 99 \\
\hline Berkum et al. [15] & 114 \\
\hline $\begin{array}{l}\text { Bergström and Magnusson } \\
{[14]}\end{array}$ & 1,005 \\
\hline Khattak and De Palma [45] & 1,218 \\
\hline Palma and Rochat [46] & 880 \\
\hline \multicolumn{2}{|c|}{ Stated adaptation } \\
\hline $\begin{array}{l}\text { Cools and Creemers [47], } \\
\text { Cools et al. [31] }\end{array}$ & 586 \\
\hline Nikolić [48] & 301 \\
\hline Petrović 2017 [34] & 678 \\
\hline Petrović et al. 2015 [49] & 285 \\
\hline Van Stralen et al. [50] & 342 \\
\hline Vu and Nguyen [44] & 100 \\
\hline
\end{tabular}

Note: Sample size in Aaheim and Hauge [7] is the number of trips, in Creemers et al. [37] it is the number of households 
Several studies [33-35] collected revealed preferences based on the panel research. In Böcker et al. [33], there were 945 respondents who recorded travel data for two days during the summer, two days during the autumn and two days during the winter. Petrović 2017 [34] conducted a panel survey with 392 respondents during the days characterised by one of the following four types of weather conditions: warm 2 - mostly dry weather, moderately warm weather with heavy precipitation, moderately cold 2 - mostly dry weather, and cold weather with heavy precipitation. Days for conducting the survey were not determined by seasons, but by the combination of the analysed meteorological conditions. Termida et al. [35] used a panel survey in the form of a longitudinal panel two-week travel diary of 67 individuals in four consecutive waves in four different seasons.

The panel household travel surveys imply observations made repeatedly on the same sample. These surveys enable the collection of travel data during specific time intervals, in this case, characterized by different weather conditions. This research approach can be particularly appropriate for countries where long-term series of national transport survey datasets do not exist. If a model is created based on the panel travel surveys, the trips are nested by research days and respondents, since an individual's adjustments to different weather conditions are probably correlated. This requires independence of recorded data to be explored [33, 37].

It is evident that the reviewed studies vary by the sample size. Sample size depends on the spatial and temporal coverage of the study, research purpose, research method, and target population size. A large sample size may contribute to a higher quality of the research, but it is more important how the sample reflects the structure of the population. In traffic studies, particularly in the household travel surveys, a stratified random sample is most commonly used [51-53]. Selecting this sampling method can be considered completely legitimate when exploring weather impacts on the travel demand. Even studies based on small representative samples may have high-quality conclusions, especially in the case of the panel survey, which is particularly significant for countries where there is no continuous travel data monitoring.

Unlike studies in which travel data in different weather conditions were collected through household travel survey, out of all the reviewed studies only two rely on the data from the automated traffic detectors. Haberl et al. [6] used data recorded on fifty permanent traffic counting stations (traffic volumes and vehicle speed) and weather measurements of eleven permanent monitoring stations for a oneyear period as a basis for the research in the federal state of Salzburg. Pillat [54] used local traffic volume and velocity data from 100 detectors as well as weather data, for a time period of four years. Data about travel time and county where the vehicle was registered were recorded on four locations using an automatic number plate recognition system for one year.

Even though the abovementioned modern technologies and equipment for traffic flow data recording are available, the household travel surveys are most commonly used to explore the weather impact on the travel demand. Furthermore, it is a fact that only the household travel surveys provide information on the travel purpose and individual decisions and choices and that modern equipment cannot provide this item of the travel demand data. The household travel surveys ensure collecting the total travel demand and its characteristics (origin, destination, purpose, mode, time) on the sample. By collecting data from the automated traffic detectors, only the total travel demand is quantified. The travel demand characteristics have to be further obtained based on the known socio-economic characteristics of the residents as well as data from the previous household travel surveys.

\section{APPLIED MODELLING PROCEDURES}

Temperature, precipitation, and wind are the most common factors included when researching the weather impact on the travel demand. Most studies take precipitation (presence and intensity of rain, snow, and hail) as the most important factor. Temperature and wind are considered less important in terms of individual's behaviour [36]; however, these have a significant impact on thermal comfort. Insolation, cloud cover, air pressure, and humidity are rarely examined [1].

Clifton et al. [2] show that sensitivity of car trips to weather conditions may be presented on a higher aggregation level (level of precipitation intensity only, not taking into account the seasonal effects) in comparison to the sensitivity of bicycle trips (level of precipitation intensity separately for each season). Cyclists are directly exposed to weather, and 
therefore models should be sensitive to seasonal weather differences. The seasons are often used to represent the usual weather conditions, particularly in modal split models, as in studies $[21,55]$. Still, the seasons may mask the daily weather variations because non-typical weather conditions for certain seasons may have a stronger influence on the decisions than usual weather conditions [2]. When creating a travel demand model that contains weather variables, the impact of weather forecast on the individuals' decisions can also be taken into account [47]. It has been demonstrated that weather forecasts affect the travel behaviour [15, 44], but this effect may certainly be considered lower than the impact of the current changes in weather conditions. Tables 2 and 3 show the components of weather conditions that are analysed and included as weather variables in trip generation and modal split models.

Evidently, the most frequently analysed components of weather conditions are the temperature, the rainfall intensity, and the wind, and these three components are analysed together in almost all the above presented research studies.
Different intensities of weather condition components have a different impact on the travel demand. The more intense weather components (heavy rain, heavy snowfall, extremely low or high temperatures, stronger wind) certainly have a greater impact on the number of trips and modal split. Vu and Nguyen [58] have shown, as logically expected, that urban flood has a stronger effect on travel behavioural changes than heavy rain. Rudloff et al. [9] concluded that the number of trips decreased with the increasing rain, where the impact on leisure trips was the largest. Different impact on transport modes was recorded: walking decreased with increasing precipitation, biking decreased but more sensitively and car driving was almost unaffected. Aaheim and Hauge [7] found that the likelihood of public transport usage increased with the intensity of precipitation and wind, compared to walking and biking. More intense rain, higher temperature or stronger wind lead to a greater probability that people prefer public transport to pedestrian and bicycle if the share of private transport is unaltered, or to private transport if the share of pedestrian and bicycle is unaltered [7]. The conclusion is that the

Table 2 - Weather variables in trip generation modelling

\begin{tabular}{|c|c|c|c|c|c|c|c|c|c|c|c|c|}
\hline & 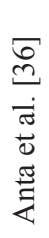 & 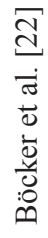 & 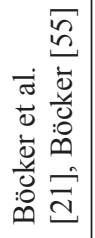 & 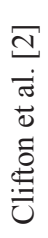 & 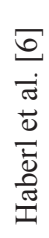 & 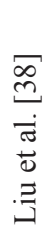 & 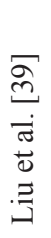 & 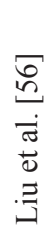 & 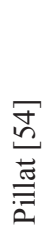 & 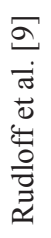 & 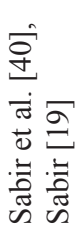 & 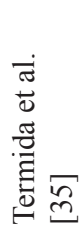 \\
\hline Average weather & & & & & & & & & + & & & \\
\hline Bad weather & & & & & & & & & + & & & \\
\hline Good weather & & & & & & & & & + & & & \\
\hline Rain duration & & & & & & & & & & & + & \\
\hline Rain precipitation intensity & + & + & & + & + & + & + & + & & + & + & \\
\hline Relative air humidity & & & & + & & + & + & & & & & \\
\hline Season & & & + & + & + & & & + & & & & \\
\hline Snowfall & & + & & & + & & & & + & & + & \\
\hline Snow/ice on road & & & & & + & + & + & + & & & & \\
\hline Sunshine duration & & & & & + & & & & & & & \\
\hline Temperature & + & + & & + & + & + & + & & & + & + & \\
\hline UTCI & & & & & & & & + & & & & + \\
\hline Visibility & & & & & & + & + & + & & & + & \\
\hline Wind & + & + & & + & & + & + & & & + & + & \\
\hline
\end{tabular}

Note: UTCI is Universal Thermal Climate Index (degrees Celsius) on the given day in the given season. UTCI was introduced in 1994. It takes dry temperature, relative humidity, solar radiation, and wind speed into account and is regarded as the reference environmental temperature causing strain. [83] 
Table 3 - Weather variables in modal split modelling

\begin{tabular}{|c|c|c|c|c|c|c|c|c|c|c|c|c|c|c|}
\hline & 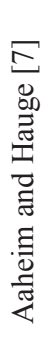 & 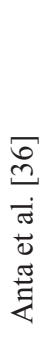 & 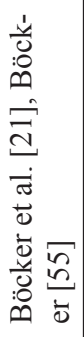 & 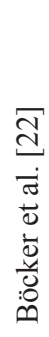 & 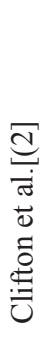 & 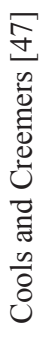 & 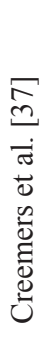 & 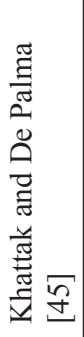 & 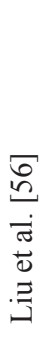 & 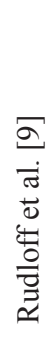 & 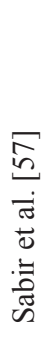 & 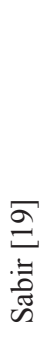 & 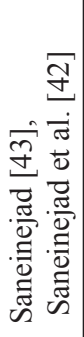 & 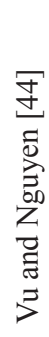 \\
\hline Adverse weather & & & & & & & & + & & & & & & \\
\hline Cloud cover & & & & & & & & & & & & & + & \\
\hline First precipitation in 7 days & & & & & & + & & & & & & & & \\
\hline Fog & & & & & & & + & & & & & & & \\
\hline Rain duration & & & & & & + & & & & & & + & & \\
\hline Rain precipitation intensity & + & + & & + & + & & + & & + & + & + & + & + & + \\
\hline Relative air humidity & & & & & + & & & & & & & & & \\
\hline Season & & & + & & + & & & & & & & & & \\
\hline Snowfall & & & & + & & & + & & & & & + & & \\
\hline Snow/ice on road & & & & & & & & & + & & & & & \\
\hline Storm & & & & & & & + & & & & & & & \\
\hline Sunshine duration & & & & & & + & & & & & & & & \\
\hline Temperature & + & + & & + & + & + & + & & + & + & + & + & + & \\
\hline Thunderstorm & & & & & & + & & & & & & & & \\
\hline Wind & + & + & & + & + & & & & & + & + & + & + & \\
\hline
\end{tabular}

bicycle traffic is under the greatest influence. Heinen et al. [59] concluded that the increase in quantity and duration of rain as well as increase in the wind strength affected cycling negatively, especially for the recreational purposes $[14,16,17]$. The increase in sunshine duration and temperature increase the probability that the commuters will cycle. On the other hand, studies $[44,58]$ have shown that mode change is very modest in all adverse weather conditions while trip cancelation, delayed departure, waiting for resuming of the trip, route change, and destination change are significant.There are several approaches to include weather conditions in the travel demand models. One approach is to directly include different weather components as continuous variables, and another is to form binary indicators (dummy variables). The third approach is the data reduction technique, which examines the covariance of different weather conditions [2].

Böcker et al. [1] criticize the modelling techniques which assume a linear relationship between weather conditions and trips. In trip generation and modal split modelling, dummy variables for certain components of weather conditions are being increasingly used. This is in accordance with the recommendations to include non-linear variables in the models [27]. Special attention should be given to the fact that certain variables, like type of household, occupation, age, gender, and car number per household, usually show a non-linear dependence. The proposed methods to include these variables into the models are either a variable transformation (linearisation) or the use of dummy variables. The use of dummy variables, in addition to solving the problem of non-linearity, usually contributes to solving the problem of multicollinearity i.e. high degree of correlation of independent variables [27].

Research studies should include impacts of weather on all aspects of travel behaviour: number of trips, spatial and temporal distribution (destination choice, departure time and trip duration) and modal split. This is the only way to determine what changes are the result of different weather conditions, as changes in travel behaviour may be interdependent. 


\subsection{Trip generation modelling}

Regression and cross-classification models are widely used in trip generation modelling. Although their results show an acceptable level of accuracy for transportation planning, these models have shortcomings as well (e.g. not taking into account the user behaviour, dependent variable can have negative or a non-integer value, which is not the case in reality). Models recommended as an alternative to conventional trip generation models are: tobit model, Poisson model, ordered logit model, ordered probit model, negative binomial model, truncated models as an alternative to regression models and multiple classification analyses as an alternative to cross-classification models [60].

A series of models were used to model the weather impact on trip generation (Table 4). These models follow the recommendations [60] for replacement of conventional models which do not take into account the user behaviour. Negative binomial and tobit models are most often used for trip generation modelling in different weather conditions. When travel demand is evaluated as the number of trips, the negative binomial model is used as a reference model for the count data. Travel demand evaluation may also be based on the distance travelled by individuals during the day and then the travel demand is estimated by the tobit model. The tobit model is implemented mainly due to the non-negative value of the dependent variable and because there is a possibility that many respondents, for example, do not have any trips of specific purpose registered during the day [55].

\subsection{Modal split modelling}

Many factors influence the travel mode choice. Models must be sensitive to numerous characteristics of the passenger, journey, and transport facilities. The multinomial logit model is commonly used in relevant studies dealing with modal split modelling that includes weather impact (Table 5) due to its simplicity. An important function of the multinomial logit model is to determine the impact of certain independent variables on the individual choice within a discrete set of options. In this case, weather is one of the independent variables and travel mode choice in different weather conditions is the dependent variable. Wider application of some other models can be expected in the future, especially in cases where panel studies should be applied.

\section{RESEARCH STUDIES IN EUROPE NOT ANALYSED BEFORE}

Weather impact on individual behaviour and travel demand was explored in regions of the USA, Australia, Europe, and Asia. The largest number of research activities was conducted in the countries of Northern Europe, mostly in the Netherlands. This indicates that the studies were conducted predominantly in the cold climate areas. A high share of non-motorized transport modes in the modal split may be highlighted as one of the main reasons for continuity in research in the Netherlands, because the users there are mainly exposed to adverse weather. After the Netherlands, this type of research is most common in the cities of Sweden and Belgium, where

Table 4 - Models used for trip generation modelling in different weather conditions

\begin{tabular}{||l|l||}
\hline \multicolumn{1}{|c|}{ Models } & \multicolumn{1}{c||}{ Authors } \\
\hline \hline Factor analysis; cluster analysis; regression models & Clifton et al. [2] \\
\hline Inverse Gaussian GEE model & Petrović 2017 [34] \\
\hline $\begin{array}{l}\text { Linear regression; cluster model; behavioural travel demand model; } \\
\text { combining cluster model and travel demand model }\end{array}$ & Pillat [54] \\
\hline Multiple regression analysis & Haberl et al. [6] \\
\hline Negative binomial & Sabir et al. [40], Sabir [19], Liu et al. [39] \\
\hline Ordered logit model & Rudloff et al. [9] \\
\hline Panel mixed ordered probit models & Liu et al. [56] \\
\hline Simultaneous tobit models & Liu et al. [38], Termida et al. [35] \\
\hline Structural equation models & Liu et al. [39] \\
\hline Tobit model & $\begin{array}{l}\text { Sabir et al. [40], Sabir [19], Böcker et al. [21], } \\
\text { Böcker [55], Liu et al. [39] }\end{array}$ \\
\hline
\end{tabular}

Note: GEE - Generalized Estimating Equations 
Petrović D, Ivanović I, Đorić V, Jović J. Impact of Weather Conditions on Travel Demand - The Most Common Research...

Table 5 - Models used for modal split modelling in different weather conditions

\begin{tabular}{||l|l||}
\hline \multicolumn{1}{|c|}{ Models } & \multicolumn{1}{c||}{ Authors } \\
\hline \hline Binary logit model & Vu and Nguyen [44] \\
\hline Binomial logit GEE model & Petrović 2017 [34] \\
\hline Generalised structural equation models & Böcker et al. [22] \\
\hline Factor analysis; cluster analysis; regression models & Clifton et al. [2] \\
\hline Mixed logit model & Rudloff et al. [9] \\
\hline MNL-GEE regression model & Cools and Creemers [47], Creemers et al. [37] \\
\hline Multinomial logit model & $\begin{array}{l}\text { Sabir et al. [41, Sabir [19], Saneinejad [43], Saneinejad et al. [42], } \\
\text { Böcker et al. [21], Böcker [55], Liu et al. [18], Anta et al. [36] }\end{array}$ \\
\hline Ordered probit model & Khattak and De Palma [45] \\
\hline Quantal response model & Aaheim and Hauge [7] \\
\hline
\end{tabular}

Note: MNL - Multinomial logit

there is also a large share of non-motorized trips [13] in the modal split. The share of non-motorized trips in Denmark is very similar [13] to the Netherlands, and Denmark is also recognized as a European country where the bicycle is the national symbol [61]. However, research on the weather conditions impact on the travel demand is not represented in Denmark as in the case of the Netherlands, Sweden and Belgium. There is also a large number of cities in Germany and Spain with significant share of non-motorized trips, but this type of research is rare.

In recent years the studies about weather impact on travel demand have been carried out in the European countries with climatic conditions significantly different from Northern Europe, like Austria, Germany, Serbia, and Spain. Most of these papers, except Anta et al. [36], have not been cited in papers dealing with weather impact on travel demand, thus indicating that insufficient attention is paid to research studies in these parts of Europe. The statement that it is important to explore the weather impact on travel demand in different climate areas is confirmed by several published papers described below.

In the province of Salzburg (Austria), Haberl et al. [6] investigated the influence of weather conditions on leisure traffic demand, as destination and departure time choice depend greatly on the season and weather conditions. The authors set up the hypothesis that weather data could be useful for a more accurate prediction of leisure trips. It was shown that temperature, sunshine hours, and fresh snowfall had the highest impact, while precipitation and snow depth had less impact on the traffic demand during the winter. During the summer, the temperature and sunshine hours had the highest impact on the traffic demand. Although the authors stressed the potential of integrating weather conditions to predict the traffic demand, the weather conditions were not considered in the demand model. The authors gave the following explanations: "still relatively low explanation for the variance of the weather parameters on traffic demand, the valid weather forecast was hard to obtain, weather phenomena and their effects differ regionally and seasonally very strongly".

Rudloff et al. [9] showed that precipitation and temperature influenced travel choices in Vienna (Austria). The highest reduction in activity was found for precipitation, hot weather, and cold weather, mainly in the case of leisure trips. Biking mainly, together with walking, is the most affected mode, while car trips are not strongly influenced by the weather. Public transport attracts more trips during the days with adverse weather and the trips are shifted from walking and biking.

In the South-eastern part of Bavaria in Germany, Pillat [54] developed methods for analysing and forecasting the impacts of weather on the traffic volume on motorways. The regression analysis showed a highly significant influence of weather on the total traffic volume, especially on leisure trips. It was also examined if the integration of weather effects in transport models would improve the forecast quality. It was concluded that the qualitative and quantitative characteristics of the weather effect were related to the day of the week, time of day and spatial location of the analysed motorway section. The quality of forecast was evaluated based on the average GEH index, which makes this particular paper the only one using this approach. The GEH 
index is a formula used in traffic engineering, traffic forecasting, and traffic modelling to compare two sets of traffic volumes. The authors concluded that the inclusion of weather effects in the cluster model increased the forecast quality in most cases, but the inclusion of weather impact in transport models did not necessarily guarantee a higher forecasting quality. It was concluded that modelling of additional influencing factors, such as holiday trips, was required in order to produce a fundamental improvement.

Petrović et al. 2015 [49] investigated the weather impact on transport supply and demand. The research showed that adverse weather conditions had a greater impact on leisure trips than on work travel. In adverse weather conditions, the employed residents usually decided to cancel their leisure trips and, to a lower percentage, to postpone them. Work trips were rarely cancelled. These changes were reflected in the mode choice and the starting time represented by the shift of the morning peak period.

The influence of weather on the motorized modes of travel (bus, rail, and passenger car, as possible alternatives) was investigated on one of the most important corridors in Barcelona (Spain). Anta et al. [36] concluded that the travellers preferred to use rail compared to the bus in adverse weather conditions. On the other hand, bus was more likely to be used than a passenger car, because of bus priority on some sections of the corridor.

\section{CONCLUSIONS FROM RECENT RESEARCH PAPERS}

The focus of the papers published in the last two years [62-67] was on the weather impact on public transport ridership in Australia, China, and the United States. These papers may be considered as indicators of the growing interest in investigating the weather impact on public transport, which further indicates that there is a non-negligible influence of weather conditions on the transport demand and mode choice. The papers from China [68] and Indonesia [69] that analyse the impact of weather conditions on taxi passengers and on online transportation (Go Car / Grab Car) indicate that the research of this kind extends to all transport subsystems.

Variations in weather conditions during the day have an impact on hourly public transport ridership, where the influence varies between peak and offpeak hours, weekdays and weekends, different transit modes and different groups of public transport users which indicate the need to investigate this subject in more detail. For the prediction of travel demand in order to create a resilient public transport system, several models have been developed. Research on the impact of weather on public transport confirms the importance of conducting research regardless of the share of non-motorized trips in the modal split, since public transport users are also significantly exposed to weather conditions during access and egress.

The most recently published paper [22] confirms the importance of research at the local level, indicating different impacts of weather conditions in different regions. It is important to perform research locally, so all specific characteristics of the area and its inhabitants could be incorporated into the demand model. Adjustments to specific characteristics of the area and its population should provide a valid prediction of weather impact on trip generation and modal split.

Travel survey methods strive toward modern technologies. Technology-mediated travel survey methods enable capturing of more details in individual travel behaviour [70] and help reporting on non-motorised trips more accurately [70, 71], help in reducing under-reporting of trips, and over-estimating of travel times, inaccuracy of locations and times [72] with the possibility of obtaining a higher quality of results [73]. Examples can be found only in $[34,49,74]$ in the form of an internet-based travel behaviour survey. The research focused on public transport ridership, mainly use of the Automatic Fare Collection (AFC) system for ridership data collection, which shows a great potential of smart technologies as a source of information that could complement or even sometimes substitute regular surveys [75].

\section{DISSCUSION AND CONCLUSION}

Modelling the travel demand for different weather conditions is important because travel demand varies significantly in different weather conditions. Models that do not take weather conditions into account cannot be considered accurate enough for the presentation of travel demand in a particular area during periods with weather conditions different than the average. The researchers who would undertake a study on this subject in the future could find the appropriate type of model for predicting the weather impact on the travel demand, according to the data collected and respecting the basic principles of 
modeling the weather impact on transport demand that are outlined in this paper. The influence of a large number of weather components on the travel demand can be examined, bearing in mind that the temperature, precipitation, and wind are represented most in the developed models.

Data obtained locally from this kind of research are of great importance for understanding the impact of weather conditions on the travel demand. Standard travel demand and supply studies are conducted in ideal weather conditions and thus the obtained values cannot be used to evaluate the operation of the transport system, nor to make traffic management decisions in adverse weather. This type of research and the conclusions drawn at the local level are necessary for realistic representations of travel behaviour in different weather conditions for the purpose of travel demand modelling. Mathematical models that have been developed in the presented studies can be further used for the modification of the standard functions in travel demand modelling software.

For comprehensive traffic modelling, it is necessary to introduce the coefficients that describe the sensitivity of both demand and supply in different weather conditions. A fact stated by Stahel [76], that there is lack of comprehensive simulation tool that can thoroughly model weather sensitivity of the transport system, is still valid. Weather-sensitive models treat impacts on transport infrastructure and driving behaviour, or include very simple activity-travel behaviour models [76]. It is not a simple process to capture all the potential effects of adverse weather conditions on transport supply and demand, to research, quantify and include them in the simulation tools. Comprehensive research on travel supply and demand in different weather conditions is particularly expensive and organizationally challenging. The application of traffic simulation software is most often related to the assessment of the weather conditions impact on the traffic system for evacuation analysis. Microscopic simulation models are a more popular tool for the evacuation analysis than mesoscopic and macroscopic models. Macroscopic models cannot present the individual vehicles behaviour in different weather conditions and mesoscopic models can track vehicle platoon dynamics, but not detailed individual vehicles behaviour [77]. Macroscopic models can show a detailed weather impact on travel demand with an activity-based models if less detailed impact on travel supply is acceptable. Agent-based micro and mesoscopic simulations were used [76-78] for traffic modelling in different weather conditions since it allows modelling of complex systems based on the behaviours of the individual actors involved [76]. Considering that in the future the goal will be to analyse the impact of weather conditions on the detailed temporal and spatial level, it would be important to define the coefficients of sensitivity of all the elements of supply and demand of the transport system so that the results can be presented in the simulation software at the micro, meso and macro levels. Simulation methods will certainly provide possibilities to test and analyse different kinds of "what-if" scenarios of the transport system [79] in different weather conditions.

It would be significant to include the traffic modelling results mentioned above in the transport master plans as they are made for the purpose of assessing the long-range investments in the transport sector. Quantifications of the weather conditions impact would be necessary in all transport sectors having in mind the comprehensiveness of the transport master plans. Future traffic demand management strategies and possible flexibility in road and street network and public transport capacities could be defined in accordance with the expected weather conditions and their impact on the transport system elements. The capacity flexibility in different weather conditions may be achieved by various traffic management models.

This literature review indicates a need to explore the weather impact on transport demand in all areas regardless of their climate. Research in local conditions is the only method of reliable identification and modelling the weather impact on the travel demand. One of the main goals of this review paper is to emphasize the importance of exploring the weather impact on travel behaviour and travel demand in areas where non-motorized modes, primarily bicycle, do not have a dominant share in the modal split. The modal shift between walking and motorized transport, as well as between public transport and passenger cars has not been sufficiently explored. The research in this field is important for defining and developing traffic management strategies, as motorized modes of transport have a high share in the modal split with a significant negative impact on the environment [80]. Besides, the fact is that the number of studies 
conducted in the developing countries is quite limited [58], so the research should be initiated in these countries as well.

In analysing and modelling the weather impact on overall travel demand, only continuous household travel surveys provide continuous travel behaviour monitoring and therefore matching travel databases with weather databases. In the absence of continuous household travel surveys, the research activities may start with a stated adaptation survey. It would serve as the basis for establishing whether or not there are changes in the travel demand in different weather conditions. If it is determined that the changes do exist, the obtained results may be validated by the revealed preferences using panel surveys. For each data collection technique mentioned herein, stratified sampling is recommended as a valid sampling method in traffic studies, particularly in travel surveys.

This review paper aims to raise awareness about research possibilities even in areas where there is no systematic traffic and travel data collection. In this case, research can rely on modern technology-mediated travel survey methods as they reduce survey costs and respondent burden. It is important to keep in mind that even studies based on small representative samples may have high-quality conclusions. Panel household travel surveys can be particularly appropriate for countries where long term series of national transport survey datasets do not exist.

Authors believe that research in this area will certainly contribute to climate adaptation within the existing strategies and procedures as part of contemporary ideas about climate adaptation as business as usual $[81,82]$. Future analysis in this research area will rely on collecting detailed data that will indicate reactions to changes in weather conditions throughout the day that often occur in short time intervals. In the future, the authors will focus on the research on the weather impact on the travel demand and supply in cities in the region, focusing on the weather effect on the modal split. An additional goal will be to show the impact of weather conditions on the transport supply and demand in traffic simulation software at the macro level. Besides, it would be interesting to conduct a research in the European cities with significant public transport share in the modal split, which may further confirm the fact that this kind of research is important in all climates regardless of the modal split.

\section{Dr DRAGANA PETROVIĆ ${ }^{1}$}

E-mail: dragana.petrovic@sf.bg.ac.rs

Dr IVAN IVANOVIĆ

E-mail: i.ivanovic@sf.bg.ac.rs

Dr VLADIMIR ĐORIĆ ${ }^{1}$

E-mail: v.djoric@sf.bg.ac.rs

Dr JADRANKA JOVIĆ

E-mail: j.jovic@sf.bg.ac.rs

${ }^{1}$ Univerzitet u Beogradu, Saobraćajni fakultet

Vojvode Stepe 305, 11000 Beograd, Srbija

\section{UTICAJ VREMENSKIH USLOVA NA \\ TRANSPORTNU POTRAŽNJU - NAJČE $\check{S} C ́ E$ METODE ISTRAŽIVANJA I PRIMENJENI MODELI}

\section{REZIME}

Rad predstavlja pregled primenjenih metoda istraživanja i razvijenih modela transportne potražnje koji uzimaju u obzir uticaj vremenskih uslova. Ovaj rad se bavi nastajanjem putovanja i vidovnom raspodelom kao elementima transportne potražnje koji najbolje opisuju promene u ponašanju putnika u različitim vremenskim uslovima. Autori naglašavaju važnost istraživanja na lokalnom nivou u svim klimatskim uslovima, posebno u oblastima u kojima se karakteristike klime $i$ vidovne raspodele razlikuju od onih u oblastima u kojima su istraživanja najčešća. Ovaj pregled osmišljen je kao kratki vodič o tome kako se može istražiti uticaj vremenskih uslova, sa ciljem podsticanja istraživanja čak i u zemljama gde ne postoji sistematsko prikupljanje podataka o saobraćaju i karakteristikama kretanja. Tehnika „,izjavljenih prilagođavanja“ praćena panel anketama o kretanjima sprovedenim na nivou domaćinstva može biti posebno pogodna za takve zemlje. Zaključeno je da mala finansijska sredstva raspoloživa za istraživanja ne bi trebalo smatrati preprekom, jer je do pouzdananih zaključaka moguće doći čak i na malim uzorcima. Štaviše, savremene metode istraživanja omogućavaju jeftinija istraživanja uz mogućnost dobijanja većeg kvaliteta rezultata. Porast popularnosti istraživanja u ovoj oblasti trebalo bi da doprinese stvaranju otpornijih transportnih sistema širom sveta. Poseban doprinos ovog rada je pregled istraživanja sprovedenih u centralnoj, zapadnoj i južnoj Evropi koja nisu pomenuta ni u jednom od prethodnih preglednih radova.

\section{KLJUČNE REČI}

uticaj vremenskih uslova; ponašanje putnika; nastajanje kretanja; vidovna raspodela; 


\section{REFERENCES}

[1] Böcker L, Dijst M, Prillwitz J. Impact of Everyday Weather on Individual Daily Travel Behaviours in Perspective: A Literature Review. Transp Rev. 2013;33(1): 71-91. Available from: https://www.tandfonline.com/doi/abs/10.1080 /01441647.2012.747114

[2] Clifton K, Chen R, Cutter A. Representing Weather in Travel Behaviour Models: A Case Study from Sydney, AUS. Australasian Transport Research Forum 2011 Proceedings, Adelaide, Australia; 2011. p. 1-14. Available from: http://www.atrf.info/papers/2011/2011_Clifton_Chen_Cutter.pdf

[3] Koetse MJ, Rietveld P. The impact of climate change and weather on transport: An overview of empirical findings. Transp Res Part D Transp Environ. 2009 May;14(3): 205-21. Available from: http://linkinghub.elsevier.com/ retrieve/pii/S136192090800165X

[4] Van Leeuwen E, Koetse M, Koomen E, Rietveld P. Spatial economic research on climate change and adaptation; Literature review for "Knowledge for Climate". Vrije Universiteit Amsterdam. KfC report number KfC 002/09, 2009. Available from: https://www. researchgate.net/publication/241866898_Spatial_economic_research_on_climate_change_and_adaptation_Literature_review_for_\%27Knowledge_for_Climate\%27_KFC_report_number_KFC_00209

[5] Ivanović I, Jović J. Sensitivity of street network capacity under the rain impact: Case study of Belgrade. Transport. 2018;33(2): 470-7. Available from: https://journals.vgtu. lt/index.php/Transport/article/view/171/138

[6] Haberl M, Neuhold R, Cik M, Fellendorf M. Modelling the demand of leisure traffic in the province of Salzburg. Proceedings of the European Transport Conference 2012, Glasgow, Scotland, UK; 2012. p. 1-17. Available from: https://www.researchgate.net/publication/306056098 Modelling_the_demand_of_leisure_traffic_in_the_province_of_Salzburg_-_Austria

[7] Aaheim HA, Hauge KE. Impacts of climate change on travel habits: A national assessment based on individual choices. Blindern, Oslo: Center for International Climate and Environmental Research; 2005. Available from: https://pub.cicero.oslo.no/cicero-xmlui/bitstream/ handle/11250/191992/CICERO_Report_2005-07.pdf? sequence $=1 \&$ is Allowed $=y$

[8] Zhang X, Chen M. Quantifying the Impact of Weather Events on Travel Time and Reliability. J Adv Transp. 2019;2019: 1-9. Available from: https://www.hindawi. com/journals/jat/2019/8203081/

[9] Rudloff C, Leodolter M, Bauer D, Auer R, Brög W, Kehnscherper K. Influence of Weather on Transport Demand. Transp Res Rec J Transp Res Board. 2015;2482(1): 1106. Available from: https://www.researchgate.net/publication/283786981_Influence_of_Weather_on_Transport_ Demand

[10] Guitink P, Holste S, Lebo J. Non-motorized transport: Confronting poverty through affordable mobility. Infrastructure Notes. Transport No. UT-4; 1994.

[11] Giffinger R, Fertner C, Kramar H, Meijers E. City-ranking of European medium-sized cities. $51^{\text {th }}$ IFHP World Congress "Future of Cities", 23-26 Sep. 2007, Copenhagen; 2007.
[12] Modal Split in ausgewählten deutschen Großstädten. Deutscher Bundestag, WD 5 - 3000 - 084/17, 2017.

[13] EPOMM. TEMS - The EPOMM Modal Split Tool. Compare cities. Available from: http://www.epomm.eu/ tems/compare_cities.phtml [cited 2020 Mar 27].

[14] Bergström A, Magnusson R. Potential of transferring car trips to bicycle during winter. Transp Res Part A Policy Pract. 2003 Oct;37(8): 649-66. Available from: http://linkinghub.elsevier.com/retrieve/pii/ S0965856403000120

[15] Van Berkum E, Weijermars W, Hagens A. The impact of weather on urban travel demand in the Netherlands. Proceedings of the EWGT2006 International Joint Conferences, Bari, Italia; 2006. p. 245-52. Available from: http://www.iasi.cnr.it/ewgt/EWGT_Atti.pdf

[16] Winters M, Friesen MC, Koehoorn M, Teschke K. Utilitarian bicycling: A multilevel analysis of climate and personal influences. Am J Prev Med. 2007;32(1): 52-8. Available from: http://www.ncbi.nlm.nih.gov/ pubmed/17184961

[17] Gebhart K, Noland RB. The impact of weather conditions on bikeshare trips in Washington, DC. Transportation. 2014;41(6): 1205-25. Available from: https://www. researchgate.net/publication/271919684_The_impact of_weather_conditions_on_bikeshare_trips_in_Washington_DC

[18] Liu C, Susilo YO, Karlström A. The influence of weather characteristics variability on individual's travel mode choice in different seasons and regions in Sweden. Transp Policy. 2015;41: 147-58. Available from: http://linkinghub.elsevier.com/retrieve/pii/S0967070X15000037

[19] Sabir M. Weather and Travel Behaviour. PhD thesis. Vrije Universiteit Amsterdam; 2011. Available from: http:// dare.ubvu.vu.nl/bitstream/handle/1871/19500/dissertation.pdf? sequence $=1$ \&isAllowed $=\mathrm{y}$

[20] Jović J. The influence of weather conditions on transport system and mobility. International Conference TES, Subotica, Serbia; 2012. p. 101-4.

[21] Böcker L, Prillwitz J, Dijst M. Climate change impacts on mode choices and travelled distances: A comparison of present with 2050 weather conditions for the Randstad Holland. J Transp Geogr. 2013 Apr;28: 176-85. Available from: http://linkinghub.elsevier.com/retrieve/pii/ S0966692312002700

[22] Böcker L, Priya Uteng T, Liu C, Dijst M. Weather and daily mobility in international perspective: A cross-comparison of Dutch, Norwegian and Swedish city regions. Transp Res Part D Transp Environ. 2019;77: 491-505. Available from: https:// reader.elsevier.com/reader/sd/pii/S1361920918306199?to$\mathrm{ken}=8$ B A 2 A 71 F 8 F 243 D 1476 D 73 D 5832 A 0F 06 DED 7789 D A 5448 F 40 E 1 D 5356 A E 1 F C 41D91A0009B553A84E152085205B49EE531F6

[23] Grujičić D, Ivanović I, Jović J, Đorić V. Customer perception of service quality in public transport. Transport. 2014;29(3): 285-95. Available from: http://www.tandfonline.com/doi/abs/10.3846/16484142.2014.951685

[24] Liu C, Susilo YO, Karlström A. Weather variability and travel behaviour - What we know and what we do not know. Transp Rev. 2017;37(6): 715-41. Available from: http://dx.doi.org/10.1080/01441647.2017.1293188 
[25] Hensher D, Rose J, Greene W. Applied Choice Analysis: A Primer. Second Ed. Cambridge: Cambridge University Press; 2015.

[26] Louviere J, Hensher DA, Swait J. Stated Choice Methods: Analysis and Applications. Cambridge: Cambridge University Press; 2000.

[27] Ortuzar J de D, Willumsen L. Modelling Transport. Fourth Ed. JohnWiley \& Sons, Ltd UK; 2011.

[28] Khademi E, Arentze T, Timmermans H. Designing stated adaptation experiments for changes to activity-travel repertoires: Approach in the context of pricing policies. European Transport Conference (ETC), Glasgow, United Kingdom; 2012. p. 1-20. Available from: https://abstracts.aetransport.org/paper/index/id/4030/confid/18

[29] Tudela A, Rebolledo G. Optimal Design of Stated Preference Experiments when Using Mixed Logit Models. European Transport Conference (ETC), Strasbourg, France; 2006. p. 1-11. Available from: https://abstracts. aetransport.org/paper/index/id/2555/confid/12

[30] Parvaneh Z, Arentze T, Timmermans H. A Stated Adaptation Approach to Assess Changes in Individuals' Activity-travel Behavior in Presence of Personalized Travel Information. Transp Res Procedia. 2014;2014(3): 21-30. Available from: http://www.sciencedirect.com/science/ article/pii/S2352146514002506

[31] Cools M, Moons E, Creemers L, Wets G. Changes in travel behavior in response to weather conditions: Whether type of weather and trip purpose matter? Transportation Research Record, Transportation Research Board; 2010. p. 1-15. Available from: https://orbi.ulg. ac.be/bitstream/2268/132905/1/TRR 10-0952 CMCW Author postscript.pdf

[32] Faivre D'Arcier B, Andan O, Raux C. Stated adaptation surveys and choice process: Some methodological issues. Transportation. 1998;25(2): 169-85. Available from: https://www.researchgate.net/publication/5088431_Stated_adaptation_surveys_and_choice_process_Some methodological_issues

[33] Böcker L, Dijst M, Faber J, Helbich M. En-route weather and place valuations for different transport mode users. J Transp Geogr. 2015;47: 128-38. Available from: https://www.sciencedirect.com/science/article/abs/pii/ S0966692315000939

[34] Petrović D. Weather impact on trip generation and modal split. $\mathrm{PhD}$ thesis. University of Belgrade, Faculty of Transport and Traffic Engineering; 2017. Serbian. Available from: http://nardus.mpn.gov.rs/bitstream/handle/123456789/9921/Disertacija.pdf?sequence=1\&isAllowed $=\mathrm{y}$

[35] Termida NA, Susilo YO, Franklin JP, Liu C. Understanding seasonal variation in individual's activity participation and trip generation by using four consecutive two-week travel diary. Travel Behav Soc. 2018;12(August 2017): 52-63. Available from: doi:10.1016/j.tbs.2017.12.006

[36] Anta J, Pérez-López JB, Martínez-Pardo A, Novales $\mathrm{M}$, Orro A. Influence of the weather on mode choice in corridors with time-varying congestion: A mixed data study. Transportation. 2016;43(2): 337-55. Available from: http://www.scopus.com/inward/record. url?eid=2-s2.0-84921889334\&partnerID=tZOtx3y1

[37] Creemers L, Wets G, Cools M. Meteorological variation in daily travel behaviour: Evidence from revealed preference data from the Netherlands. Theor Appl Climatol. 2015;120(1-2): 183-94. Available from: http://link. springer.com/10.1007/s00704-014-1169-0

[38] Liu C, Susilo Y, Karlstrom A. Examining the impact of weather variability on non-commuters' daily activitytravel patterns in different regions of Sweden. $J$ Transp Geogr. 2014 Jul;39: 36-48. Available from: http://linkinghub.elsevier.com/retrieve/pii/S0966692314001331

[39] Liu C, Susilo YO, Karlström A. Investigating the impacts of weather variability on individual's daily activity-travel patterns: A comparison between commuters and non-commuters in Sweden. Transp Res Part A. 2015;82: 47-64. Available from: doi:10.1016/j.tra.2015.09.005

[40] Sabir M, van Ommeren J, Koetse MJ, Rietveld P. Impact of weather on daily travel demand. Working paper, CROW Fietsberaad, 2010. Available from: http://www. fietsberaad.nl/library/repository/bestanden/Sabir et al (2010a).Pdf

[41] Sabir M, Koetse MJ, Rietveld P. The Impact of Weather Conditions on Mode Choice: Empirical Evidence for the Netherlands. $17^{\text {th }}$ Annual conference EAERE. Amsterdam, Holland; 2009. p. 1-24. Available from: http:// www.webmeets.com/files/papers/EAERE/2009/1021/ Sabir.pdf

[42] Saneinejad S, Roorda MJ, Kennedy C. Modelling the impact of weather conditions on active transportation travel behaviour. Transp Res Part D Transp Environ. 2012 Mar;17(2): 129-37. Available from: http://linkinghub. elsevier.com/retrieve/pii/S1361920911001143

[43] Saneinejad S. Modelling the Impact of Weather Conditions on Active Transportation Travel Behaviour. Master Thesis. University of Toronto; 2010. Available from: https:// tspace.library.utoronto.ca/bitstream/1807/25793/6/Saneinejad_Sheyda_201011_MASc_thesis.pdf

[44] Vu AT, Nguyen TTH. Analysis of Mode Choice Behavior under Adverse Weather Conditions Using RA and SA Surveyst - A Case Study from Ho Chi Minh City (HCMC), Vietnam. Proceedings of the $5^{\text {th }}$ International Conference on Geotechnics, Civil Engineering Works and Structures, CIGOS 2019, Innovation for Sustainable Infrastructure; 2019. p. 959-64.

[45] Khattak AJ, De Palma A. The impact of adverse weather conditions on the propensity to change travel decisions: A survey of Brussels commuters. Transp Res Part A Policy Pract. 1997;31(3): 181-203. Available from: http://linkinghub.elsevier.com/retrieve/pii/S0965856496000250

[46] Palma ADE, Rochat D. Understanding individual travel decisions: Results from a commuters survey in Geneva. Transportation. 1999;26(3): 263-81. Available from: https://www.researchgate.net/publication/226999460 Understanding_individual_travel_decisions_Results_ from_a_commuters_survey_in_Geneva

[47] Cools M, Creemers L. The dual role of weather forecasts on changes in activity-travel behavior. J Transp Geogr. 2013 Apr;28: 167-75. Available from: http://linkinghub. elsevier.com/retrieve/pii/S0966692312002682

[48] Nikolić M. Impact of weather conditions on travel demand in Belgrade. Master Thesis. University of Belgrade, Faculty of Transport and Traffic Engineering; 2011. Serbian. 
[49] Petrović D, Ivanović I, Djorić V. Does Weather Impact on Commuters' Travel Demand - Empirical Case Study of Belgrade. European Transport Conference (ETC), Frankfurt, Germany; 2015. p. 1-11. Available from: https://www.researchgate.net/publication/292143625 DOES WEATHER IMPACT ON COMMUTERS'_TRAVEL_DEMAND_-_EMPIRICAL_CASE_ STUDY OF BELGRADE

[50] Van Stralen W, Calvert SC, Molin EJE. The influence of adverse weather conditions on the probability of congestion on Dutch motorways. Eur J Transp Infrastruct Res. 2015;15(4): 482-500. Available from: http://www.trb. org/AnnualMeeting2014/AnnualMeeting2014.aspx

[51] Richardson AJ, Ampt ES, Meyburg AH. Survey Methods for Transport Planning. First ed. Melbourne, Australia: Eucalyptus Press; 1995. Available from: http://www. no2hcf.co.uk/docs/Traffic_survey_form.pdf

[52] Paskota M. Sample design and survey error. Seventh International Conference on Travel Survey Methods, Costa Rica; 2004. p. 1-27. Available from: https://pdfs.semanticscholar. org/5917/83fe665d032492b261a2480e40c9c3968243. pdf? ga $=2.50703721 .1948720205 .1577437569$. 2029327699.1573495925

[53] Paskota M. [Methodology for quantitative research]. University of Belgrade, Faculty of Transport and Traffic Engineering; 2007. Serbian.

[54] Pillat J. Methoden zur Analyse und Prognose des Verkehrsaufkommens unter Berücksichtigung des Wetters auf Autobahnen. Universitat Stuttgart; 2014. Available from: https://d-nb.info/1064308902/34

[55] Böcker L. Climate, Weather and Daily Mobility - Transport Mode Choices and Travel Experiences in the Randstad Holland. PhD thesis. Faculty of Geosciences, Utrecht University; 2014. Available from: http://dspace.library. uu.nl/handle/1874/315942

[56] Liu C, Susilo YO, Karlström A. Measuring the impacts of weather variability on home-based trip chaining behaviour: A focus on spatial heterogeneity. Transportation. 2015;43(5): 843-67. Available from: http://link. springer.com/10.1007/s11116-015-9623-0

[57] Sabir M, van Ommeren J, Koetse M, Rietveld P. Welfare Effects of Adverse Weather through Speed Changes in Car Commuting Trips. Tinbergen Inst Discuss Pap. 2008;TI 2008-08: 1-23. Available from: http://papers. tinbergen.nl/10029.pdf

[58] Vu AT, Nguyen TTH. Travel behavior change patterns under adverse weather conditionst - A case study from Ho Chi Minh City (HCMC), Vietnam. Proceedings of the $5^{\text {th }}$ International Conference on Geotechnics, Civil Engineering Works and Structures, CIGOS 2019, Innovation for Sustainable Infrastructure; 2019. p. 921-6.

[59] Heinen E, Maat K, Wee B Van. Day-to-Day Choice to Commute or Not by Bicycle. Transp Res Rec J Transp Res Board. 2011;2230(1): 9-18.

[60] Chang JS, Jung D, Kim J, Kang T. Comparative analysis of trip generation models: Results using home-based work trips in the Seoul metropolitan area. Transp Lett Int $J$ Transp Res. 2014;6(2): 78-88. Available from: http:// www.maneyonline.com/doi/abs/10.1179/194278751 4Y.0000000011
[61] Agervig Carstensen T, Ebert A-K. Chapter 2 Cycling Cultures in Northern Europe: From 'Golden Age' to 'Renaissance'. In: Cycling and Sustainability. 2015. p. 23-58.

[62] Li J, Li X, Chen D, Godding L. Assessment of metro ridership fluctuation caused by weather conditions in Asian context: Using archived weather and ridership data in Nanjing. J Transp Geogr. 2018;66(35): 356-68. Available from: doi:10.1016/j.jtrangeo.2017.10.023

[63] Zhou M, Wang D, Li Q, Yue Y, Tu W, Cao R. Impacts of weather on public transport ridership: Results from mining data from different sources. Transp Res Part C Emerg Technol. 2017;75: 17-29. Available from: doi:10.1016/j. trc.2016.12.001

[64] Ngo NS. Urban bus ridership, income, and extreme weather events. Transp Res Part D Transp Environ. 2019;77: 464-475. Available from: doi:10.1016/j. $\operatorname{trd} .2019 .03 .009$

[65] Miao Q, Welch EW, Sriraj PS. Extreme weather, public transport ridership and moderating effect of bus stop shelters. J Transp Geogr. 2019;74(August 2018): 12533. Available from: doi:10.1016/j.jtrangeo.2018.11.007

[66] Wei M, Corcoran J, Sigler T, Liu Y. Modeling the Influence of Weather on Transit Ridership: A Case Study from Brisbane, Australia. Transp Res Rec. 2018;2672(8): 505-10. Available from: https://www.researchgate.net/ publication/325583780_Modeling_the_Influence_of Weather_on_Transit_Ridership_A_Case_Study_from_ Brisbane_Australia

[67] Tao S, Corcoran J, Rowe F, Hickman M. To travel or not to travel: 'Weather' is the question. Modelling the effect of local weather conditions on bus ridership. Transp Res Part C Emerg Technol. 2018;86(November 2017): 14767. Available from: https://reader.elsevier.com/reader/ sd/pii/S0968090X1730311X?token=183652E623BCA2594F34D3E507558B9D28AE96521574CA8032E702B32AFA614F9EFEBAA243AFD0421AEC9CFF832DA398

[68] Chen D, Zhang Y, Gao L, Geng N, Li X. The impact of rainfall on the temporal and spatial distribution of taxi passengers. PLoS One. 2017;12(9): 1-16. Available from: https://journals.plos.org/plosone/article?id=10.1371/ journal.pone.0183574

[69] Rakhmatulloh AR, Dewi DIK, Wijayanti, Winarendri J. Effect of Weather for Demand of Online Transportation in Tembalang, Semarang. The $2^{\text {nd }}$ International Conference on Smart City Innovation, IOP Conference Series: Earth and Environmental Science; 2019. p. 1-8. Available from: https://iopscience.iop.org/article/10.1088/1755-1315/396/1/012018/pdf

[70] Safi H, Assemi B, Mesbah M, Ferreira L. An empirical comparison of four technology-mediated travel survey methods. J Traffic Transp Eng. 2017;4(1): 80-7. Available from: doi:10.1016/j.jtte.2015.12.003

[71] Rudloff C. Can technologically assisted travel surveys improve mode choice modelling? Differences and improvements compared to travel conventional survey data. Proceedings of $7^{\text {th }}$ Transport Research Arena TRA 2018, Vienna, Austria; 2018. p. 1-10. Available from: https://www.researchgate.net/publication/324747315 Can_technologically_assisted_travel_surveys_improve mode choice modelling Differences and improvements compared to travel conventional survey data 
[72] Zhao F, Pereira FC, Ball R, Kim Y, Han Y, Zegras C, et al. Exploratory Analysis of a Smartphone-Based Travel Survey in Singapore. Transp Res Rec J Transp Res Board. 2015;2494(1): 45-56. Available from: https:// dusp.mit.edu/sites/dusp.mit.edu/files/attachments/ news/Smartphone-Based_Travel_Survey.pdf

[73] Wermuth M, Sommer C, Kreitz M. Impact of new technologies in travel surveys. In: Transport Survey Quality and Innovation; 2003. p. 455-81. Available from: https://pdfs.semanticscholar.org/4230/d9e9f2fdc2ad0e24057803b6449c4c5f3fd2.pdf

[74] Zanni AM, Ryley TJ. The impact of extreme weather conditions on long distance travel behaviour. Transp Res Part A Policy Pract. 2015;77: 305-19. Available from: doi:10.1016/j.tra.2015.04.025

[75] Arana P, Cabezudo S, Peñalba M. Influence of weather conditions on transit ridership: A statistical study using data from Smartcards. Transp Res Part A Policy Pract. 2014;59: 1-12. Available from: https://www.sciencedirect.com/science/article/pii/S0965856413002073?via\%3Dihub

[76] Stahel A, Ciari F, Axhausen K. Modeling impacts of weather conditions in agent-based transport microsimulations. Transportation Research Board Annual Meeting, Washington, D.C.; 2014. p. 1-21.

[77] Aljamal MA. Comparison of Microscopic and Mesoscopic Traffic Modeling Tools for Evacuation Analysis. Master Thesis. Virginia Tech; 2017.

[78] Heyndrickx C, Rodric F, Bösch PM, Ciari F. Benefits of informing travellers in case of extreme precipitation events, A model based case study for Zurich using MATSim;2015.Available from: https://www.research-collection.ethz.ch/bitstream/handle/20.500.11850/249865/ ab1108.pdf?sequence $=1 \&$ isAllowed $=y$

[79] Kostrzewski M. Implementation of distribution model of an international company with use of simulation method. Procedia Eng. 2017;192: 445-50. Available from: doi:10.1016/j.proeng.2017.06.077

[80] Burchart-Korol D, Folęga P. Impact of road transport means on climate change and human health in Poland. Promet - Traffic Transp. 2019;31(2): 195-204. Available from: https://traffic.fpz.hr/index.php/PROMTT/article/ view/3074/561561752

[81] Quinn AD, Ferranti EJS, Beckford J, Dora JM. Adaptation Becoming Business as Usual: A Framework for Climate-Change-Ready Transport Infrastructure. Infrastructures. 2018;3(10): 1-12. Available from: https:// www.mdpi.com/2412-3811/3/2/10

[82] Schwanen T. Transport geography, climate change and space: Opportunity for new thinking. J Transp Geogr. 2019;81(September): 1-8. Available from: https://www. mdpi.com/2412-3811/3/2/10

[83] Zare S, Hasheminejad N, Shirvan HE, Hemmatjo R, Sarebanzadeh K, Ahmadi S. Comparing Universal Thermal Climate Index (UTCI) with selected thermal indices/ environmental parameters during 12 months of the year. Weather Clim Extrem. 2018;19(March): 49-57. Available from: doi:10.1016/j.wace.2018.01.004 